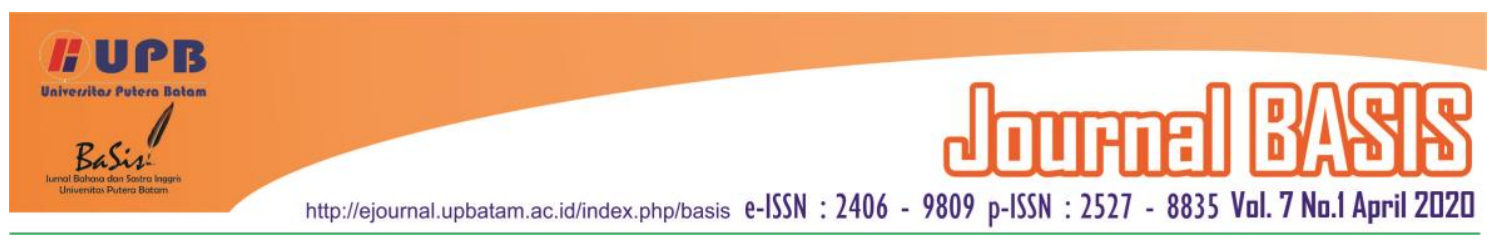

\title{
GRAMMATICAL AND LEXICAL COHESION ANALYSIS OF TRUMP'S SPEECH UPON SOLEIMANI ASSASSINATION
}

\author{
Vidya Mandarani ${ }^{1}$ \\ University of Muhammadiyah Sidoarjo (UMSIDA), East Java, Indonesia \\ vmandarani@umsida,ac.id \\ Muhammad Zuhri Fakhruddin ${ }^{2}$ \\ University of Muhammadiyah Sidoarjo, East Java, Indonesia \\ mz.fakhruddin93@gmail.com
}

\begin{abstract}
This study specifically examined the grammar and lexical cohesion of a speech from one of the controversial figure, Donald Trump, regarding with a current reckless assassination upon Iran's highest general, Qasem Soleimani, in early 2020. Such investigation required the use of textual analysis of a designated speech from a YouTube video, which transcripted further be thoroughly examined. The results showed that Trump positively justified his action while negatively claim the opposite of his addressee. This was shown with the most frequent form of cohesion for the grammatical section is the reference with 65 pieces of evidence, as well as near-synonym and repetition with only 9 evidence for lexical section. While the least form is the conjunction with 23 evidence, also both synonym and general word with only 1 evidence. This also highlighted that the use of some cohesion features displays a different aim and effect. All in all, this study presented a theoretical implication, where all elements of a related proper speech entailed the use of grammatical and lexical cohesion altogether.
\end{abstract}

Keywords: discourse analysis; grammatical cohesion; lexical cohesion; speech

\section{INTRODUCTION}

Over more than a millennium, as a social being, humans have long been known for utilizing languages as their means of communication. Throughout the passage of history, language by its role has identified for the cause that triggered several momentous yet influential events for both good and ill. Its presence may serve as both an amplifier and simplifier for a certain message, which further influences others who eventually received the message. One powerful manifestation of this is none other than a speech itself. Countless figureheads have since been recognized for their breathtaking speeches. Varying from ancient peoples, such as prophets or philosophers, renowned leaders, or simply some individuals of today's era. A speech simply is a vocalized form of human communication. It means that speech itself is heavily related to sounds reproduction by human articulatory organs. Since its production revolves around human's audial organs, speech may possess various features like its style, pitch, intonation, and many others. These variables make a speech as a rather unique language form of medium for conveying a message.

Frequently, a speech by influential persons often encompasses a special purpose, such to express his or her opinion and deliver an overview along with essential things and events. One of the common domains of analyzing critical discourse covers public speech by which the speaker is trying to gain audiences' best responses 
(Wahyuningsih, 2018). Bradac, Cargile, \& Hallet (2001) also emphasized that several experts have dedicated most of their time in studying how speakers' use of language prompts a reaction from their listeners. Regarding with public speaking, a speech by Donald Trump over Iran's highest general, Qasem Soleimani, in early 2020, may seem interesting to discuss considering his reputation and power in the United States of America. Moreover, the Presidential speech is regarded as the most elected representatives of the country in which the utterances have the semantic load of the nation particularly the ethos and soul (Adetunji, 2006; Rullyanti \& Sriwigati, 2018). However unique it is, a speech remained bounded with basic traits of oral language. These traits are grammatical and lexical cohesion.

In that regard, a speech is believed to possess quite a few examples of both grammatical and lexical cohesion. Moreover, the speech itself came from one of the most popular yet controversial figure, Donald J. Trump. His assassination deed upon Iran's top general was justified through his speech, which nonetheless piqued researchers' interest since such latest political turbulence in early 2020 sparked many worldwide-case disputes.

\section{LITERATURE REVIEW}

As mentioned in the introduction passage previously, discourse is the device to cover an analytical framework for the analysis of an actual text and talk within a communication context. Therefore, Critical Discourse Analysis (CDA) itself is a type of discourse analytical research, which primarily studies on how social power abuse, dominance, and inequality are passed, replicated and resisted by both texts and talk within a social and political context
(Van Dijk, 1985). According to Wang (2010), critical discourse analysis may enable people to describe the connection between language, ideology and power altogether. Following that, the interpersonal function has given the influences upon the diversity of discourse analytic approaches to modality (Halliday, 1978).

Regarding related studies of discourse analysis, previous studies are undertaken by some researchers. First, a study by (Wahyuningsih, 2018) that shows the use of personal pronouns as the attempt to maintain a better social role and communication in his, Donald Trump, inauguration speech. Second, a study by Sujito \& Muttaqin (2019) explained that Trump has been implemented an ideological manipulation on his addressee to win the U.S. election. He utilized such subtle ideological discourse structure, which could be classified into two strategies of positive self-presentation and negatively impact otherpresentation. This statement also supported by Cynthia (2019), that language used by Hillary Clinton that has been manipulated to influence the audiences about her ideology. She also tends to represent her addressee with a negative representation. Contrary from these studies, this research is going to unveil the content and tendency of Trump's speech, and how he justifies his act over the hot issue of assassination upon Iran's highest general, through the analysis of grammatical and lexical cohesion.

The study of cohesion itself is predominantly connected with discourse analysis (Tambunan, 2019), while its context is inseparable from what we regarded as a text. Texts are a thing that is written and printed, such as transcripts of spoken communication The term itself is originally used to refer 
an appropriateness property, which characterizes a particular text compared to another mere sequence of words. The concept of cohesion elaborates relations of meaning that exist inside a text (Salkie, 1995). It occurs when the elements within the text are being mutually dependent on each other in a sense that it cannot be decoded except by recourse. This coexistence of elements builds the relationship up and realized a cohesive structure in the text. Similar to that notion, Janjua (2012) also clarified that cohesion is a relationship amongst structurally standalone text elements, which function is to distinguish text from the collection of unconnected sentences. Since it has a lot in common with all semantic system components, Tanskanen (2006) added that cohesion manifested through both grammar and vocabulary. Thus, cohesion, in general, is divided into two major elements namely structural (grammar) and nonstructural (lexical) (Halliday \& Hasan, 1976).

Grammatical cohesion has categorized into four types. First, reference that concentrating upon the connections between a text's discourse and its preceding subsequent element. The reference itself is divided into three types: personal, demonstrative and comparative. Second, substitution which is as implied by its name, it is a replacement process of an item by another one. It holds a text together, averting repetition and establishing such a unified grammatical wording within the sentences. It contains three types: nominal, verbal and causal. Third, ellipsis that primarily refers to an omission process upon word or part of the sentence and it contains three types: nominal, verbal and clausal. Fourth, conjunction which is a connective element, which indicates how the consequent phrases or clauses ought to be linked to the preceding or the following (part of the) sentence. Four types of conjunction: additive, adversative, causal and temporal. While lexical cohesion divided into two types. First, reiteration that is a type of lexical cohesion that comprises the repetition of a lexical item, the use of the general word to reversely denote towards lexical items, and several kinds of stuff between synonym, near-synonym, or superordinate. Four types of reiteration: repetition, synonym, near-synonym, general word. Second, collocation which revolves around the connection between the words of the fact, which is also called as lexical cohesion that achieved through lexical items association that systematically co-occur. These cohesions are not only represented by a synonym or superordinate, yet also by opposite pairs various kinds.

Many linguists and writers still believe that merely lexical cohesion can make a text more coherent. This creates a possibility that a text lacking lexical cohesion still can be more coherent. Even if the term of cohesion and coherence emerge hand in hand in the realm of literature, the relationship between them is still disputed (McCarthy, 1991). Both grammatical and lexical possess semantic relation in making compact and dense sentences arrangement for speech production (Nurjannah, 2013).

\section{RESEARCH METHOD}

As an attempt to deliver the best possible outcome from this study, researchers utilized textual analysis as the appropriate approach to find out issue-oriented in a social context within the forms of text and talk (Fairclough, 2003; Van Dijk, 1988). The data obtained are originated from a YouTube 
video, under the title of "President Trump Delivers a Statement on Iran" which was uploaded by The White House channel on January 4th, 2020, with viewers amounting to more than 322 thousand and counting (House, 2020). The text obtained is a video transcription directly subtracted from the clip. This research data will be in a qualitative descriptive form to provide in-depth and resourcefulness to an investigation, as well as interpreting the data in detailed description (Wahyuni, 2012). Further, the data will be presented in the form of words, phrases and sentences, which are existed within the targeted video transcript. Researchers will try to interpret pieces of evidence of both grammatical and lexical cohesion. From the present evidence, a classification was made to assists researchers and readers in comprehending what kinds of cohesion existed within the speech and how the evidence will support the analysis of discourse.

\section{RESULT AND DISCUSSION}

Before delving further into the investigation, it is worth mentioning that the video taken by the researchers is about 04:15 minutes long. Fortunately, the video was added with English captions to facilitate non-native viewers in understanding the content. From the captions, researchers were able to subtract a written transcript, which later will be divided into 5 (five) texts in total. From these paragraphs, each type of both grammatical and lexical cohesion will be investigated.

\subsection{Text 1}

The analyzed data are taken from the video around 00:03 - 00:39. Researchers then found two forms of grammatical cohesion as follows:

Reference a. The personal reference is used to address the act between him and the targeted personality. The speaker has emphasized his stance as President who must protect his people from the evilness carried out by the person namely Qasem Soleimani. The use of 'We' elaborates a systematic action directed by an organized chain of command, from President to the military forces. Written as follow:

Soleimani was plotting imminent and sinister attacks on American diplomats and military personnel, but we caught him in the act and terminated him.

b. Demonstrative references are used for specifying the situation, such in [a flawless precision strike that killed number one terrorist] and [...in the act] and the level of the act; like in [...number one terrorist anywhere in the world].

\section{Conjunction}

Most conjunctions used in the paragraph are additive. It shows additional information giving a sense of importance; like in [...my highest and most solemn duty] and [imminent and sinister attacks on American diplomats]. Another function of the use is to elaborate additional information and sequence; like in [...American diplomats and military personnel] and [...in the act and terminated him].

\subsection{Text 2}

The analyzed data are taken from the video around 00:40 - 01:32. Researchers then found two forms of grammatical and three forms of lexical cohesion respectively as follows:

Reference

a. The personal reference is still to explain the acts carried out by the targeted person who caused him being assassinated. 
We will find you; we will eliminate you. We will always protect our diplomats, services members, all Americans and our allies.

b. Demonstrative reference is less than in the first paragraph, and it mostly acts as an explainer of the entity; like in [...the Islamic Revolutionary Guard Corps]. It also acts as an explainer of the situation; like in [...carried out under the directions of Soleimani].

\section{Conjunction}

The conjunction 'or' is used to explained alternative entity or act which possibly caused to be recognized as the enemy by the speaker; like in [To terrorists who harm or intend to harm any American]. Meanwhile, the conjunction 'and' are mostly used to explain additional information in the paragraph; like in [....all Americans and our allies].

\section{Repetition}

The repetition 'will' in [We will find you; we will eliminate you. We will always protect our diplomats, services members, all Americans and our allies] gives a strong sense of intention to do the act. Here, the speaker wants to emphasize that he will do any necessary actions over those who are considered as an enemy, as he also emphasized his commitment to protect his people and allies.

Near-synonym

The near-synonym 'targeted, injured, murdered, killed' are used in the paragraph to highlight the cruel action claimed by the speaker over the targeted personality.

.....has targeted, injured and murdered hundreds of American civilians and servicemen. ....including rocket strikes that killed an American and injured four American servicemen very badly.

General Word

There is only one general word in the paragraph. It is the IRGC (Islamic Revolutionary Guard Corps) which is a broader term for the Iranian military organization, while the Quds Force is the special force inside it.

\subsection{Text 3}

The analyzed data are taken from the video around 01:33 - 03:08. Researchers then found both 2 forms of grammatical and lexical cohesion as follows:

\section{Reference}

a. Personal references, such 'We' and 'I' are used by the speaker to explain himself and his administration stance against the act of enemy; like in [Today we remember and honor the victims of Soleimani many atrocities, and we take comfort in knowing that his reign of terror is over] and [ $I$ have deep respect for the Iranian people].

b. Demonstrative

references are mostly used to point entity and its characteristic; like in [the brutal repression of protesters....].

Conjunction

The distinctive conjunction of 'as......as' explains the range of activities which possibly taken by the person considered as the enemy by the speaker; like in [...contributing to terrorist plots as far away as New Delhi and London]. The other conjunctions have taken place as unifying unit to the additional information for the sentence.

Repetition 
The repetition 'must end' is taking a role as stressing phrase over the act. The speaker stated it to attract and to show his sympathy over the Iranian people and its neighbours. Written as follow:

However, the Iranian regime's aggression in the region, including the use of proxy fighters to destabilize its neighbors must end, and it must end now.

Near-synonym

There are four near-synonyms 'tortured, killed, remember, remarkable' and all of them are used to emphasize the broader heart-taking situation of the audience to agree with the speakers' mean. It also explains how badly the personality which is considered as the enemy by the speaker. Thus, the killing is justifiable.

\subsection{Text 4}

The data are taken from the video around 03:09- 04:06. Researchers then found three forms of grammatical and one form of lexical cohesion respectively as follows:

\section{Reference}

There are two comparative references in the paragraph those are; [...has the best military by far] and [The world is a safer place without....]. The first is explaining the superiority, while the second explains the comparison between two things (before the killing and after the killing). The other references are just playing their roles as an explainer of the entity and a different stance between the speaker and the object.

Conjunction

Most conjunctions in this paragraph are used to explain the state of the entity; like in [The world is a....] and [the interest of good people...].

\section{Repetition}

The repetition occurs when the speaker addresses the people of Iran. He creates repetitions to attract and to show his care over Iranian people and that he does not mean to confront, but their leader. Written as follow:

America will always pursue the interests of good people, great people, great souls, while seeking peace harmony, and friendship with all of the nations of the world.

Synonym

The only synonym used in this paragraph is 'ready' and 'prepared'. Although these two words came from different root both give similar sense. The use of this synonym is to highlight the state of preparation made by the state led by the speaker.

\subsection{Text 5}

The analyzed data are taken from the video around 04:06 - 04:15. Researchers then found three forms of grammatical cohesion as follows:

\section{Reference}

The references are 'you' and 'our' used to address the audiences as the speaker wants to convince them to agree with his act and decision before closing his speech, such as [God bless you, God bless our great military].

\section{Conjunction}

The only one conjunction 'and' is used to unite the sentence before closing, such as [God bless our great military and God bless the United States of America].

Repetition 
The speaker mentioned 'Thank you' and repeated three times. These are used to show the wise and polite stance of the speaker before the speech ended.

Upon these utterances said by Donald Trump during his speech regarding his feat of assassinating Iran's top general, Qasem Soleimani, it was found that many cohesion elements present within the speech itself. Although not all, several points are eminent, such as reference and conjunction from structural section; as well as repetition, synonym and nearsynonym from non-structural section. The most frequent form of cohesion found is, the reference with as many as 65 pieces of evidence for grammatical section, also both repetition and nearsynonym with only 9 evidence for lexical section. While the least form of cohesion found is, conjunction with as many as 23 evidence for the grammatical section as well as the synonym and general word with only 1 evidence for lexical section. However, researchers also found no evidence for some kinds of cohesion from both grammatical and lexical units, like substitutions, ellipses, superordinate and collocation. Moreover, Trump's speech delivers a message to his audiences that under his leadership, he has taken action to stop a war. He recalled what he did to ISIS territorial caliphate and recently eliminated a terrorist leader known as Al-Baghdadi. This figure is assumed to be hostile towards Islam, hence it was shown upon his speech that Islamic people possess a possibility in becoming terrorist, which will trigger a war. Indirectly, he shows himself as a figure to worth for gratitude since he has terminated a way for terrorists. This is the only mean to self-justification; his accomplished deed.

\section{CONCLUSION}

In a brief, Donald Trump in his speech showed that as long as the highest orders are within his grasp, he will eradicate all terrorism that has plunged the world into an unsafe place, especially for U.S. citizens. In other words, he deliberately considered his deed as a positive mean and his addressee's deed as the opposite altogether. Such inference is supported by the findings that the most frequent form of cohesion is the reference with as many as 65 pieces of evidence for grammatical section, as well as nearsynonym and repetition with only 9 evidence for lexical section. Whereas, the least form of cohesion is the conjunction with as many as 23 evidence for grammatical section. There are no evidence for substitution, ellipsis, superordinate and collocation. This study also presents a theoretical implication, where all elements of a related proper speech entails the use of grammatical and lexical cohesion altogether. The findings highlighted that the use of some cohesion features displays a distinctive aim and effect, as such repetition signifies an importance of an information, or a distinct referencing that is used to put a different labeling as 'they' and 'us', and many more. Such findings are also expected to encourage more researcher and linguist alike, to perform such inquiry in examining popular speeches from many renowned individuals

\section{REFERENCES}

Adetunji, A. (2006). Inclusion and Exclusion in Political Discourse: Deixis in Olusegun Obasanjo's Speeches. Journal of Language and Linguistics, 5(2), 177-191. http://webspace.buckingham.ac.uk/ kbernhardt/journal/5_2/LING\%202 .pdf 
Bradac, J., Cargile, A., \& Hallet, J. (2001). Language Attitudes: Retrospect, Conspect and Prospect. In H. Giles \& W. . Robinson (Eds.), The New Handbook of Language and Social Psychology (pp. 137-155). UK: Wiley.

Cynthia, D. A. (2019). LGBT Issue as Human Rights in Hillary Clinton's Speech on Human Rights Campaign Organization: A Critical Discourse Analysis. Islamic University of Sunan Ampel Surabaya.

Fairclough, N. (2003). Analysing Discourse: Textual Analysis for Social Research. New York: Routledge.

Halliday, M. A. (1978). Language as Social Semiotic: The Social Interpretation of Language and Meaning. London: Edward Arnold.

Halliday, M. A., \& Hasan, R. (1976). Cohesion in English (English La). London: Longman.

House, T. W. (2020). President Trumpt Delivers a Statement on Iran. In The White House Youtube Channel. Retrieved from https://www.youtube.com/watch?v $=$ TYY29yO8HIc\&feature $=$ youtu.b e

Janjua, F. (2012). Cohesion and Meanings. Canadian Social Science, $\quad 8(2), \quad$ 149-155. http://dx.doi.org/10.3968/j.css.192 3669720120802.2060

McCarthy, M. (1991). Discourse Analysis for Language Teachers. UK: Cambridge University Press.
Nurjannah, S. (2013). Cohesion in Barack Obama's Second Victory Speech Discourse Analysis. Hasanuddin University.

Rullyanti, M., \& Sriwigati, H. (2018). An Analysis of Lexical Cohesion Used by Donald Trump's Inauguration Speech "The United States will be The First" (2017). Literary Criticism, 4(2), 68-77. Retrieved from https://jurnal.unived.ac.id/index.ph p/jlc/article/view/688

Salkie, R. (1995). Text and Discourse Analysis (1st ed.). https://doi.org/10.4324/978020313 8144

Sujito, I., \& Muttaqin, M. W. (2019). Critical Discourse Analysis on Donald Trump's Strategy against His Addressee to Win the US Election. IJOTL-TL, 4(1), 75-84. https://doi.org/10.30957/ijotltl.v4i1.554

Tambunan, M. A. (2019). Lexical and Grammar Cohesion in the Collection of "Museum Penghancur Dokumen" Poetry By Afrizal Malna. Jurnal Basis, 6(2), 185.

https://doi.org/10.33884/basisupb.v 6i2.1426

Tanskanen, S.-K. (2006). Collaborating towards Coherence. Philadelphia: John Benjamins Publishing Company.

Van Dijk, T. A. (1985). A Handbook of Discourse Analysis. London: London Academic Press Limited.

Van Dijk, T. A. (1988). News as Discourse. New Jersey: Lawrence 
Erlbaum Associates Publisher.

Wahyuni, S. (2012). Qualitative Research Method: Theory and Practice. Jakarta: Salemba Empat.

Wahyuningsih, S. (2018). A Discourse Analysis: Personal Pronouns in Donald Trump's Inauguration Speech. ELLiC Proceedings, 2, 346-350.

Wang, J. (2010). A Critical Discourse Analysis of Barack Obama's Speeches. Journal of Language Teaching and Research, 1(3), 254261.

https://doi.org/10.4304/jltr.1.3.254261 
